\title{
Tomasz Gąsowski
}

\section{IDEA NIEPODLEGEOŚCI W POWOJENNEJ POLSCE}

\author{
Cmentarze rosną, maleje liczba obrońców \\ ale obrona trwa i będzie trwała do końca \\ i jeśli Miasto padnie a ocaleje jeden \\ on będzie niósł Miasto w sobie po drogach wygnania \\ on będzie Miasto.
}

Zbigniew Herbert, Raport z oblężonego Miasta, 1982

Rozpocznę od cytatu, który uważam za klucz do przesłania mojego artykułu. A oto i on:

Powstanie Kościuszkowskie zakończyło I Rzeczpospolitą, ale jako walka o niepodległość nie przestało trwać w rozmaitych formach po rok 1918. II Rzeczpospolita skończyła się Powstaniem Warszawskim i powstanie to trwa nadal w rozmaitych formach i będzie trwać aż do powstania III Niepodległości.

Powstanie Kościuszkowskie nie miało żadnych szans zwycięstwa, ale nigdy nie było potępiane w szerszych kręgach. Rozumiano, że bez tej walki Polska nie mogłaby żyć dalej jako naród. Ludzie decydujący w roku 1944 też wiedzieli, że powstanie nie ma żadnych szans, ale nie mogli się zgodzić na utratę niepodległości, na komunizm, na oddanie Wilna i Lwowa. Powstanie roku 1794 miało za hasło „całość i niepodległość”. W roku 1918 zrealizowano je tylko częściowo. O ile uda się zrealizować postulaty roku 1944, to trudno powiedzieć, o ile w ogóle naród polski dotrwa do III Niepodległości

W liście pisanym w 1984 r. przez wybitnego znawcę dziejów Polski w XIX i XX wieku do drugiego, młodszego o pokolenie, ale również świetnego, historyka zawarta jest pewna, niekoniecznie jedyna możliwa, interpretacja losu Polaków

${ }^{1}$ Henryk Wereszycki (Lwów 1898-1990) do Tadeusza Łepkowskiego (Wilno 1927-1989), Kraków 1984. 
w ostatnich dwu stuleciach ${ }^{2}$. Losu, którego głównym wyznacznikiem był opór przeciw zniewoleniu jednostki i narodowej wspólnoty. Ten właśnie los w trwały sposób odcisnął swe piętno na polskiej tożsamości narodowej.

Postępujące już od pierwszej połowie XVIII stulecia, takie pełzające zniewolenie ostatecznie dopełniło się przed jego końcem i trwało następne dwa wieki z krótką, niespełna dwudziestoletnią przerwą na czas II Rzeczpospolitej. Dotknęło ono kilku - siedmiu, może ośmiu pokoleń członków narodowej wspólnoty. Ta narodowa wspólnota Polaków nowego typu została po raz pierwszy zdefiniowana jeszcze przed ostatecznym upadkiem Rzeczpospolitej, bo w preambule Trzeciomajowej Konstytucji. Mowa jest w niej o narodzie polskim, a dalszy ciąg tego znakomitego tekstu stanowi - moim zdaniem - polską wersję Deklaracji Niepodległości. Wsłuchajmy się w jego brzmienie:

(...) wolni od hańbiących obcej przemocy rozkazów, ceniąc drożej nad życie, nad szczęśliwość osobistą, egzystencję polityczną, niepodległość zewnętrzną i wolność wewnętrzną narodu (...) z największą stałością ducha niniejszą Konstytucję uchwalamy (...)

Znajdujemy w niej bowiem jasny i zwarty wykład tego czym jest owa niepodległość. Jest ona tu zdefiniowana jako wolność „negatywna”, tj. wolność od przemocy. I równocześnie bardzo mocno została wyrażona wola jej obrony. A gdy się to nie powiodło żołnierzom Kościuszki i legionistom Dąbrowskiego, sposób skutecznego wybicia się na nią wskazał Polakom w 1800 roku sam Naczelnik w publikacji, będącej rodzajem jego testamentu dla potomnych spisanego przez jego sekretarza Józefa Pawlikowskiego Czy Polacy wybić się moga na niepodległość? Od tego się wszystko zaczęło. Albowiem pierwsze niepowodzenia nie zniechęciły Polaków do kolejnych prób wybicia się na niepodległość, czyli „wyjarzmienia”, jak wówczas często mówiono i pisano. W czasie powstania listopadowego brzmiała strofka śpiewanej potem długo w wielu polskich domach piosenki:

Pamiętaj żeś Polka, że o kraj to walka.

Niepodległość Polski to twoja rywalka.

Romantyczny duch tej epoki dał nam wówczas skreślone piórem francuskiego poety jeszcze mocniejsze, bezkompromisowe wezwanie w dumnej pieśni Warszawianka, którą usłyszeć można i współcześnie:.

${ }^{2}$ E. Orman, Historyk i jego historia. Próba biografii Henryka Wereszyckiego, [w:] H. Wereszycki, Historia w życiu historyka, red. E. Orman i A. Cetnarowicz, Kraków 2001, s. 42 i n. 
Powstań Polsko, skrusz kajdany,

Dziś Twój tryumf albo zgon ${ }^{3}$

Takie postawienie sprawy spotęgowali tworzący na emigracji polscy romantycy. W Księgach pielgrzymstwa polskiego wieszcz Adam Mickiewicz wzywał rodaków do modłów O niepodległość, całość i wolność Ojczyzny naszej. Walkę o niepodległość traktowano coraz częściej jako patriotyczny obowiązek stający przed każdym pokoleniem Polaków. W epoce romantycznych uniesień przeżywanych na uchodźstwie przez ludzi niemających już właściwie nic do stracenia polska idea niepodległości została wzbogacona o nowe cechy. Były to: bezkompromisowość i radykalizm oraz walor etyczny, polegający na mocnym przeświadczeniu, że obowiązek walki o niepodległość stanowi dla każdego Polaka niepodważalny składnik etyki zasad. Narzucała ona zatem wybór określonego systemu wartości, w którym ważne miejsce zajmował etos rycerski ${ }^{4}$.

Taka właśnie postać polskiej idei niepodległości uformowana ostatecznie pod koniec XIX stulecia stała się niejako obowiązującym wzorcem przekazywanym poprzez edukację, kulturę i bezpośredni żywy przykład kolejnym pokoleniom Polaków. W przyszłości stało się to źródłem bardzo poważnych konsekwencji, nad którymi warto się jednak zadumać. Albowiem wierność pryncypiom prowadziła do kolejnego zderzenia z trzema zaborcami, a następnie po 1918 roku z dwoma imperiami. Piętno takiej właśnie postawy znajdujemy nie tylko w kolejnych zrywach powstańczych czy rzucaniu przez Strzelców Komendanta na stos losu swego młodego życia. Znajdujemy je także w fundamentalnych decyzjach politycznych i militarnych roku 1939 i 1944 . Nie mogę się w tym miejscu powstrzymać przed zacytowaniem ostatniego zdania z przyjętej owacyjnie mowy sejmowej min. Józefa Becka 5 maja 1939 r. "Jest jedna tylko rzecz w życiu ludzi, narodów i państw, która jest bezcenna. Tą rzeczą jest honor" ${ }^{5}$. Konsekwencje takiej właśnie postawy i zrodzonej z niej decyzji ujawniły się już niebawem.

Trzeba wszelako zauważyć, że pod koniec XIX stulecia pojawił się i został zwerbalizowany w polskiej myśli politycznej także drugi, odmienny sposób pojmowania idei niepodległości. Można go określić mianem defensywnego, minimalistycznego, a może po prostu racjonalnego. Jego priorytetem była obrona stanu posiadania, a więc po pierwsze biologicznej i po drugie materialnej egzystencji narodu. Wyrażany i propagowany przez część polskich elit już znacznie wcześniej w postaci

${ }^{3}$ J. F. C. Delavigne, Warszawianka 1831, przeł. K. Sienkiewicz, muz. K. Kurpiński, pierwodruk: Polak sumienny, Warszawa, marzec 1831.

${ }^{4}$ Z. Najder, Niepodległość, [w:] Węzły pamięci Niepodległej Polski, red. Z. Najder, Warszawa 2013, s. 157 i n.

${ }^{5}$ Mowa ministra Józefa Becka, „Gazeta Lwowska”, 6 maja 1939, s. 1-2. 
„pracy organicznej”, trafiał do niektórych umysłów, ale nie budził emocji, nie poruszał polskiego ducha, więc nie miał szans na sukces, na wyparcie poprzednika ${ }^{6}$.

I tak oto nadszedł decydujący rok 1944, w którym Polska i Polacy decyzją trzech wielkich mocarstw poddani zostali następnemu zniewoleniu ${ }^{7}$. Po kilku latach intensywnego, ale stopniowo słabnącego oporu musieli ulec przemocy. Różnorodne formy tego oporu - politycznego, zbrojnego, społecznego zostały do 1949 r. ostatecznie brutalnie stłumione. Pozostawiły jednak po sobie trwały ślad w pamięci oraz wskazania dla Polaków na przyszłość zawarte m.in. w ostatnim rozkazie ostatniego Komendanta Głównego AK „Niedźwiadka” - gen. Leopolda Okulickiego (19 stycznia 1945), w Testamencie Polski Walczącej (Manifest do Narodu Polskiego i Narodów Zjednoczonych) z 1 lipca 1945 r. czy Deklaracji Ideowej Zrzeszenia Wolność i Niezawisłość („Wolność obywatela, niezawisłość państwa: wytyczne ideowe”, wrzesień 1945) ${ }^{8}$.

W następującym teraz okresie ostrego stalinizmu, trwającym do 1956 roku, mamy do czynienia już tylko z nielicznymi próbami tworzenia konspiracji o niepodległościowym obliczu. Pojawiały się one jeszcze przede wszystkim w kręgach młodzieży szkolnej. To owi „spóźnieni Kolumbowie”, młodsi bracia żołnierzy Polski Walczącej, którzy nie dorośli na czas próby ${ }^{9}$. Ważna bez wątpienia jest też nadal obecność Kościoła, co prawda dalekiego od buntowniczych poczynań, ale próbującego do czasu, wbrew piętrzonym przeszkodom, realizować ofiarnie swą misję. I wreszcie zrządzeniem Opatrzności mamy jego głowę - młodego prymasa Polski, Stefana Wyszyńskiego. Dla wielu Polaków, zgodnie z polską tradycją, będzie on odtąd aż do swej śmierci, także interrexem, symbolizującym niepodległość państwa, a tym przypadku jej ideę właśnie. Uwięzienie prymasa we wrześniu 1953 roku wstrząsnęło polskim Kościołem, umożliwiając jego - na szczęście tylko chwilowe - zniewolenie ${ }^{10}$.

Począwszy od 1956 roku, w zmienionym znacznie po śmieci Stalina klimacie politycznym, w Polsce, wówczas już PRL, następują istotne wydarzenia, łagodzące

${ }^{6}$ Droga do niepodległości czy program defensywny? Praca organiczna - programy i motywy, oprac. T. Kizwalter, J. Skowronek, Warszawa 1988, s. 47 i n.

${ }^{7} \mathrm{O}$ nieprzemijających kontrowersjach wobec postawy niezłomnej obrony wartości materialnych, ale w jeszcze większym stopniu duchowych, której szczególnym symbolem stało się Powstanie Warszawskie zob. Spór o Powstanie. Powstanie Warszawskie w powojennej publicystyce polskiej 1945-1981, oprac. D. Gawin, Warszawa 2004. Zob. także T. Łubieński, Bić się czy się nie bić?: o polskich powstaniach, Warszawa 1997 oraz tegoż Ani tryumf, ani zgon: Szkice o Powstaniu Warszawskim, Warszawa 2004.

${ }^{8}$ S. Korboński, Przewodnik po Podziemiu z lat 1939-1945, Warszawa 2008, s. 258 i n.

${ }^{9}$ Stawiliśmy opór... Antykomunistyczne organizacje młodzieżowe w Małopolsce w latach 1944-1956, red. A. Roliński, J. Wójcik, Kraków 2008.

${ }^{10}$ Zob. Stuga Boży kardynat Stefan Wyszyński (1901-1981). Co Kościót i Polska zawdzięczaja Prymasowi Tysiąclecia?, red. S. Budzyński i in., Warszawa 2000. 
stopniowo represyjność władzy sprawowanej nadal w imieniu Moskwy przez komunistów. Ciąg tych wydarzeń otwiera krwawo stłumiona rewolta robotnicza w czerwcu 1956 roku w Poznaniu z hasłami „wolności i chleba”, ale też „my chcemy Boga”. W ślad za nią pojawiają się jednak procesy społeczne i kulturowe, będące przejawami różnych form społecznego oporu przeciw zniewoleniu. W większym lub mniejszym stopniu wykraczały one poza formułę wspieranej różnymi formami przymusu „strategii przystosowania”, uprawianej z konieczności przez większość społeczeństwa. W strategii tej można dokonywać, rzecz jasna, pewnych rozróżnień. Ująć występujące tu postawy i zachowania na swoistej skali - od pełnej akceptacji i świadomego uczestnictwa w trwającym nadal systemie komunistycznego zniewolenia, przez różne przejawy oportunizmu, czyli po prostu uległości, aby się tylko nie narazić władzy, aż po owo przystosowanie, mające czysto defensywny charakter.

Często padające stwierdzenie: „Trzeba przecież jakoś żyć!” było samousprawiedliwieniem, ale przecież nie pozbawionym racjonalności. Sformułowana przez znakomitego emigracyjnego pisarza i zarazem zażartego antykomunistę Józefa Mackiewicza dyrektywa głosząca, że po 1945 roku jedyne miejsca godnej egzystencji Polaków to komunistyczne więzienia lub emigracja, nie mogła być przecież żadną miarą stosowana w skali masowej ${ }^{11}$. W tym miejscu muszę jednak przywołać ważną dyskusję na ten temat, jaka w swoim czasie miała miejsce pomiędzy dwoma świetnymi znawcami epoki, reprezentującymi różne generacje, ale przede wszystkim odmienne orientacje ideowe. Mam na myśli spór między Tomaszem Strzemboszem a Andrzejem Friszke wokół istnienia versus nieistnienia owego społecznego oporu Polaków. Osobiście przychylam się do zdania prof. Strzembosza i dlatego o nim wspominam ${ }^{12}$. Doceniam też jego rolę w przechowaniu idei niepodległości, o czym niżej.

Wspólnym mianownikiem poszczególnych aktów oporu społecznego, mających charakter jawnych, otwartych protestów np. intelektualistów czy nawet demonstracji różnych środowisk będzie obecnie, tj. po zwrocie politycznym w 1956 roku, hasło „więcej wolności!”. Wolności w różnych dziedzinach życia, formach, przejawach, wolności tak dla jednostki jak też poszczególnych grup społeczeństwa. Jednak brakuje wśród nich hasła wolności dla całego narodu, czyli niepodległości. No i to charakterystyczne dla tych czasów samoograniczenie - „więcej”, to wszak nie znaczy pełniej! Słowo „niepodległość” jest nadal kłopotliwe, niekiedy wręcz

${ }^{11}$ Szerzej o tym zob. G. Eberhardt, Pisarz dla dorostych: opowieść o Józefie Mackiewiczu, Wrocław 2008.

${ }^{12}$ T. Strzembosz, Polacy w PRL: sprzeciw, opozycja, opór. Zachowania opozycyjne w systemie totalitarnym, „Studia Polityczne” (2000) nr 11, s. 137 i n. Inaczej A. Friszke, Opozycja polityczna w PRL 1945-1980, Londyn 1994, s. 47 in. oraz Przystosowanie i opór. Studia z dziejów PRL, Warszawa 2007. 
wstydliwie skrywane i tak będzie do końca lat 70., szczególnie w kręgach intelektualistów, subtelnie kontestujących czasami niektóre strony życia w PRL. O nielicznych wyłomach w tym milczeniu powiem dalej.

Dla usprawiedliwienia, czy może raczej wyjaśnienia takiej właśnie orientacji różnych „niepokornych” środowisk pojawiających się w PRL trzeba wskazać na pewną realnie istniejącą kwestię ${ }^{13}$. Jej źródło stanowiła trudność w zdefiniowaniu statusu tego tworu państwowego. Innymi słowy idzie tu o odpowiedź na z pozoru banalne pytanie - czym jest, dziś na szczęście tylko: czym był PRL? Odpowiedzi padały różne, a rozbieżności ocen jego natury nie znikły także współcześnie. A zatem niepodlegle państwo, niepodległe państwo, ale o ograniczonej suwerenności, rodzaj dominium, kolonia, czy jeszcze coś innego? Były to raczej teoretyczne tylko dywagacje nielicznych. Natomiast istotny był przede wszystkim fakt, że dla rosnącej stale ówczesnej populacji Polaków, potem także ich dzieci, był to jedyny, realnie istniejący polski twór państwowy jaki znali, więc jakaś wyimaginowana niepodległość nie mieściła się w ich horyzoncie intelektualnym.

A wracając do przerwanego wątku, spróbuję teraz dokonać porządkującej typologii przejawów opozycyjności, czy szerzej form krytycznego dystansu Polaków wobec ówczesnego systemu politycznego. Ważnych, bo stanowiących przecież, moim zdaniem, istotne podłoże dla kultywowania idei niepodległościowej, której poszukujemy w PRL. A zatem będą to:

- Działania zmierzające do obrony wolności i swobód: religijnych, pracowniczych, związkowych, kulturalnych, praw człowieka i obywatela, ochrony krajobrazu naturalnego i dziedzictwa kulturowego. Wszystkie one należą wprawdzie do kategorii, „praw człowieka i obywatela”, ale do połowy lat 70. nie była ona wyraźniej eksponowana w PRL. Tu też umieściłbym, choć nie bez wahań, nieco późniejszy ruch pacyfistyczny.

- Działania w obronie autonomii instytucji (szkoły wyższe, redakcje wydawnictw i zwłaszcza czasopism, ruch harcerski, ruch oazowy, ruch Światło-Życie, dalej Kluby Inteligencji Katolickiej etc.). Ważny był tu nawet sam fakt ich obecności i funkcjonowania. Tu także zaliczyłbym duszpasterstwa akademickie ${ }^{14}$. Niektóre z nich, jak choćby dominikańska „Beczka” w Krakowie, były od połowy lat 70. prawdziwą „wylęgarnią” młodych opozycjonistów.

- Opozycja demokratyczna lat 70. z pewnymi wyjątkami mieściłaby się we wcześniejszych ujęciach, jest jednak konstrukcją już mocno osadzoną w narracji historycznej i trudno ją pominąć. Charakterystyczna dla jej aktywności opozycyjność

${ }^{13}$ Określenie takie zastosowane w odniesieniu do generacji młodych Polaków z końca XIX w. wprowadził do szerszego obiegu B. Cywiński, zob. B. Cywiński, Rodowody niepokornych, wyd. 1, Warszawa 1971, zob. też A. Friszke, A. Paczkowski, Niepokorni. Rozmowy o Komitecie Obrony Robotników, Kraków 2008.

${ }^{14}$ K. Jarkiewicz, Duszpasterstwa akademickie Krakowa po II wojnie światowej, Kraków 2004. 
„niepolityczna” była rodzajem kamuflażu, który ułatwiać miał działalność, usypiając czujność władz; na ogół nieskutecznie.

- Dalej wymieniłbym nieformalne środowiska i grupy zamknięte, nieprowadzące otwartej działalności publicznej ani konspiracyjnej. Broniły one jednak poczucia narodowej wspólnoty, tradycji, zasad, dobrego obyczaju, pamięci o II Rzeczpospolitej. Uczestnikiem jednej z takich grup był „Wujek” Karol Wojtyła. Inne z krakowskiego tylko podwórka to tzw. „Klub prof. Wereszyckiego” czy nieliczne grono ludzi skupionych wokół redakcji „Znaku” i „Tygodnika Powszechnego”. Ale w i w innych większych miastach ówczesnego PRL-u, funkcjonowały podobne gremia. Niekiedy działo się to nawet pod przykryciem legalnych instytucji np. PTTK i oczywiście Klubów Inteligencji Katolickiej ${ }^{15}$. Zazwyczaj skupione wokół centralnej postaci o pięknej biografii, działacza politycznego czy kombatanta przyciągały ludzi młodszego, powojennego już pokolenia.

- Rolę taką w pewnych sytuacjach mogły też pełnić organizacje czysto „reżimowe", np. harcerstwo, a zwłaszcza niektóre jego kręgi czy środowiska, dalej PAX, a nawet związki zawodowe, jak to niekiedy miało miejsce ${ }^{16}$.

- Zdarzało się także, co prawda niezbyt często, że utwory pojawiające się w oficjalnym nurcie kultury PRL zawierały zamieszczone tam celowo, mniej lub bardziej zakamuflowane, np. przy użyciu historycznych kostiumów, niepodległościowe przesłania. Pomimo tego maskowania były zazwyczaj dla większości Polaków łatwe do odczytania. Bywało jednak, że takie przesłanie pojawiało się przypadkowo, bez a może nawet wbrew intencji twórcy i oczywiście przy chwilowym uśpieniu czujności cenzury. Świadczy o tym przypadek filmu Bogdana Poręby z 1973 roku Hubal. W trakcie jego projekcji miały miejsce przypadki spontanicznej, patriotycznej reakcji widzów.

- Najtrudniej zdefiniować niezwykle ważne przejawy oporu występujące niekiedy w społeczności wiejskiej czyli wśród chłopstwa. Rzadko przybierał on bowiem formy zorganizowane czy zinstytucjonalizowane, bywał najczęściej chwilowy ale czasami masowy, a nawet powszechny - np. samorzutna likwidacja wiejskich spółdzielni produkcyjnych na przełomie lat 1956/57. Czasami dotyczył również kwestii religijnych jak obrona „swoich” księży czy też uczestnictwo w nielegalnej budowie kościołów ${ }^{17}$.

- A skoro o tym mowa to również trzeba odnotować rolę uczestnictwa w zabronionych przez władze uroczystościach religijnych, jak pielgrzymki, np. peregrynacja obrazu Matki Boskiej częstochowskiej, procesje Bożego Ciała, obchodzenie

${ }^{15}$ P. Kaźmierczak, Klub Inteligencji Katolickiej w Krakowie w latach 1956-1989, Kraków 2009.

${ }^{16}$ Zob. W. Hausner, M. Wierzbicki, Sto lat harcerstwa, Warszawa 2015, s. 324 i n.

${ }^{17}$ Poczatki niezależnego ruchu chłopskiego 1978-1980. Komitet Samoobrony Chłopskiej Ziemi Lubelskiej, oprac. M. Choma-Jasińska, M. Krzysztofik, Lublin 2008. 
zniesionych świąt etc. Nie można pominąć przypadków takich jak „obrona krzyża” w Nowej Hucie w 1960 roku przez mieszkańców tego nowego, socjalistycznego z założenia miasta. A generalnie rzecz ujmując, trzeba podkreślić fakt funkcjonowania w dalszym ciągu historycznie ukształtowanego związku mocnej wówczas jeszcze polskiej religijności z patriotyzmem. Był on czymś oczywistym i naturalnym dla ówczesnych Polaków, w pewnym sensie docenianym także przez władze.

- Osobne wreszcie miejsce zająć musi nauczanie papieskie od pierwszej pielgrzymki do ojczyzny w czerwcu 1979 roku oraz jej owoc zrodzony już rok później - „Solidarność, konfederacja wolnych Polaków, wielki i zarazem wielonurtowy ruch społeczny, różnie dziś z tego powodu klasyfikowany. To jednak bardziej złożona kwestia, wymagająca odrębnego potraktowania.

W każdym przypadku przejawy te miały własne motywacje, specyfikę, formy i czas działania, a także inicjatorów i lokalnych, najczęściej chwilowych przywódców. Ciąg tych zdarzeń jawi się czasem jako szeroki innym razem wąski, szybko lub przeciwnie leniwie z pozoru płynący nurt, co sprawia trudność przy próbie jakiegoś, choćby tylko ogólnego ogarnięcia ich skali, intensywności, czasu trwania i przede wszystkim efektywności i skutków.

Jeśli teraz poszukiwać miejsc czy środowisk, w których orientacji naczelne miejsce zajmowała właśnie idea niepodległości, ciągle żywa, ważna i kultywowana, a rozumiana jako posiadanie niepodległego (i suwerennego) państwa, to trzeba najpierw wskazać na tysiące polskich domów i polskich rodzin, wychowujących dzieci, a może nawet częściej wnuki, w takim właśnie patriotycznym duchu. Jego naczelną osnowę stanowiła bowiem niepodległościowa tradycja, zarówno w postaci idei jak też rozlicznych przykładów służenia jej i urzeczywistniania, zaczerpniętych z dalszej i bliższej przeszłości, dzieł kultury, także przeżyć i doświadczeń własnych lub rodzinnych. I dalej, kultywowanie pamięci o wydarzeniach i bohaterach, opowieści o dumnej przeszłości Rzeczypospolitej. Aktywną formą jej pielęgnowania była opieka nad kombatantami czy też troska o cmentarze lub pojedyncze mogiły. Albowiem oprócz pamięci duchowej, kulturowej duże znaczenie miała ochrona materialnych śladów niepodległości, tej niedawnej - czyli Polski odrodzonej i tej bardziej odleglej np. powstańczej. Stąd starania o zachowanie ciągle jeszcze rozsianych w wielu miejscowościach Polski różnego rodzaju pomników, tablic, obelisków, płyt czy innych form upamiętnienia niepodległości i jej obrońców, poczynając od konfederatów barskich, a kończąc na wojennych i powojennych czasach. Wszystko to stanowiło i stanowi nadal tzw. węzły pamięci. Ich bogactwo i formy odtwarza i dokumentuje cytowane już obszerne wydawnictwo pod redakcją Zdzisława Najdera Węzły pamięci Niepodległej Polski (Warszawa 2013).

Bardzo ważną rolę na tym polu odegrały środowiska kombatanckie. One same były bowiem takimi żywymi węzłami a ponadto promieniowały na innych, prze- 
kazując zasoby swej pamięci kolejnym generacjom Polaków. Było ich wiele i nie sposób tu wszystkich wyliczać, dlatego ograniczę się do wskazania w tym miejscu tylko trzech. Pierwsze, mające poniekąd charakter centralny, to środowisko jasnogórskie, korzystające z gościny i opieki oo. paulinów. Jego centralną postacią był w latach 70. gen. dr Roman Abraham (1891-1976), pod koniec życia traktowany nawet przez władze PRL jako nieformalny reprezentant żołnierzy II Rzeczpospolitej. Ich widoczna aktywność polegała przede wszystkim na inicjowaniu i współorganizowaniu obchodów patriotycznych - 3 maja i 11 listopada, dalej 6 i 15 sierpnia, 1 września i in. rocznic. Także na organizowaniu pielgrzymek kombatantów i ich rodzin do jasnogórskiej „Hetmanki”. Drugie to środowisko „wawelskie” złożone z legionistów, strzegących grobu Marszałka i próbujących chronić jego kopiec przed całkowitą dewastacją. Ci najstarsi żołnierze Rzeczpospolitej pozostawali pod szczególną opieką ze strony syna żołnierza, kard. Karola Wojtyły. Najważniejszą postacią był wśród nich kiedyś najmłodszy żołnierz I Brygady płk Józef Herzog (1901-1983) ${ }^{18}$. Wspomnę też z osobistych powodów wywiadowczynię I Brygady Zofię Zawiszankę-Kernową i jej opowieści o Komendancie ${ }^{19}$. Środowisko to, ciągle jeszcze aktywne, odgrywało szczególną rolę także dlatego, że tym czasie, tj. latach 70., symbolem numer jeden polskiej niepodległości stał się bezdyskusyjnie marszałek Józef Piłsudski i tak jest zresztą jest po dziś dzień. I wreszcie krąg trzeci, skupiał grono akowców, głównie Inspektoratu „Jodła”, a więc związanych z kielecczyzną. Kulminacyjnym punktem ich działań były coroczne uroczystości upamiętniające legendarnego partyzanta „Ponurego”, porucznika czasu wojny Jana Piwnika, obchodzone od lat 60. w sierpniu na leśnej polanie Wykus, m.in. z częstym udziałem ks. Józefa Tischnera.

We wszystkich tych wydarzeniach, a przecież nie wolno zapominać o działalności stowarzyszeń Rodzin Katyńskich, Powstańców Warszawskich i wielu innych jeszcze środowisk, uczestniczyli oprócz samych kombatantów także członkowie ich rodzin oraz, co może najważniejsze, obecne były spore grupy ludzi młodych. Władze komunistyczne piętrzyły nadal liczne przeszkody, a organizatorów takich imprez Służba Bezpieczeństwa nękała na różne sposoby, jednak represje nie były już tak dotkliwe jak poprzednio. W PRL zmieniał się bowiem po raz kolejny polityczny klimat. Symbolicznym znakiem był fakt, iż 11 listopada 1968 roku władze państwowe po raz pierwszy uczciły oficjalnie przypadającą wówczas 50 rocznicę odzyskania niepodległości. Zelżała także cenzura, umożliwiając historykom 2010.

${ }^{18}$ Józef Herzog, Żołnierz Niepodległości: wspomnienia i dokumenty, oprac. P. Wywiał, Kraków

${ }^{19}$ T. Gąsowski, Zofii Zawiszanki (1889-1971) trzy czerwone róże, [w:] Polacy i Świat. Kultura i zmiana. Studia historyczne i antropologiczne, oprac. J. Lencznarowicz, J. Pezda, A. A. Zięba, Kraków 2016, s. 253-270. 
i publicystom podejmowanie zakazanych dotąd tematów, czy też formułowanie ocen odbiegających od obowiązującej dotychczas partyjnej wykładni ${ }^{20}$.

Trzeba też mieć na uwadze fakt, że w ciągu całego okresu powojennego istniał i funkcjonował na obczyźnie żywy relikt II Rzeczpospolitej w osobie jej władz na czele z prezydentem na uchodźstwie. Przechodził on różne koleje losu, ale swą misję symbolu niepodległości i legalizmu ośrodek ten i tworzący go ludzie wypełniali wzorowo do końca ${ }^{21}$. Kontakty między ośrodkiem londyńskim a krajem siłą rzeczy były luźne i sporadyczne, niemniej począwszy od lat 60. zostały wznowione, choćby z racji powiązań rodzinnych. Dla trudnej do określenia części Polaków w różnym wieku ich trwała obecność, wierność idei i zasadom, stanowiły ciągle ważny punkt odniesienia i myślenia o przyszłości. Władze II RP na uchodźstwie otaczał niezmiennie szacunkiem również Jan Paweł II.

Żywsze i pełniejsze kontakty istniały z innymi ośrodkami emigracyjnymi, podtrzymującymi również ideę niepodległości. Były to rozgłośnie radiowe, na czele z rozgłośnią polską Radia Wolna Europa. Ważnym centrum wolnej polskiej myśli politycznej i twórczości artystycznej był Instytut Literacki Jerzego Giedroycia z jego sztandarowym organem, paryską „Kulturą”, utrzymujący w latach 70. wcale żywe i bezpośrednie kontakty z krajem ${ }^{22}$. Pewną rolę odgrywały także inne instytucje emigracyjne; Instytuty Piłsudskiego (Londyn i Nowy Jork), Studium Polski Podziemnej, Polski Uniwersytet Na Obczyźnie, Fundacja Kościuszkowska czy Kongres Polonii Amerykańskiej. Każda z nich na swój sposób starała się przecież służyć idei niepodległości, traktując to jako swą nadrzędną misję. Efekty ich działań w niewielkim tylko stopniu docierały do kraju, wpływając na poglądy i emocje części Polaków, także młodych, ale zjawisko takiego przenikania miało jednak miejsce.

I na koniec, spójrzmy na fenomen tzw. opozycji demokratycznej zrodzonej w PRL w poł. lat 70. Po latach wszystkie jej nurty, na końcu z „Solidarnością,, chętnie przypisują sobie zasługi w odzyskaniu przez Polskę niepodległości. Można się zgodzić co do tego, że ich istnienie i działanie osłabiające komunistyczny reżim w pewien sposób przyczyniało się do tego końcowego efektu. Nigdy jednak nie stawiano niepodległości w sposób otwarty jako nadrzędnego celu. Trzeba to jasno powiedzieć. Co więcej, gdy pojawiały się takie zorientowane niepodległościowo środowiska, były one mocno krytykowane, posądzane o „ubecką prowokację" i z tej racji ostro zwalczane przez reprezentantów „głównego nurtu”23.

${ }^{20}$ Szerzej o tym zob. R. Stobiecki, Historiografia PRL: ani dobra ani mądra ani piękna...ale skomplikowana. Studia i szkice, Warszawa 2007.

${ }^{21}$ A. Friszke, Życie polityczne emigracji. Druga wielka emigracja 1945-1990, t. 1, Warszawa 1999 , s. 29 i n.

${ }^{22}$ K. Pomian, W kręgu Giedroycia, Warszawa 2000, w wielu miejscach.

${ }^{23}$ J. R. Sielezin, Koncepcje i spory programowe opozycji politycznej w PRL w latach 1976-1982, Wrocław 2012, 16 i n. 
W niewielkim zakresie zacznie się to zmieniać dopiero pod koniec 1981 roku. Tym bardziej warto docenić te nieliczne gremia, które jednak nie poddały się ostracyzmowi dominującego, lewicowego nurtu, dla którego nieśmiałym marzeniem była co najwyżej tzw. „finlandyzacja”. Nie miejscu tu by szczegółowo rozpatrywać ich działalności, ale trzeba oddać im sprawiedliwość i docenić niepodległościowe zaangażowanie. Sporo zresztą już na ten temat napisano, cenne są także publikacje dokumentów programowych.

Pierwsze z nich to Polskie Porozumienie Niepodległościowe, a sama jego nazwa wiele mówi. Było to nieliczne (ok. 60 osób) zakonspirowane środowisko intelektualistów działających w latach 1975-1981, którego skład poznaliśmy stosukowo niedawno. Jego inicjatorem był Zdzisław Najder, a obok niego współtworzyli PPN kierując też jego pracami Jan Olszewski, Andrzej Kijowski, Wojciech Karpiński, Jan Józef Szczepański. Ich działalność, przypomnę, konspiracyjna, a w każdym razie niejawna i pozbawiona struktur, ograniczała się do prac programowych, analizujących aktualne położenie Polski i poszukających dróg do odzyskania niepodległości niezbędnej, zdaniem jej członków, dla normalnego życia narodu. Ta właśnie teza stanowiła zasadniczy punkt wyjścia dla aktywności politycznej tego środowiska. Jej ostatecznym celem była niepodległa Rzeczpospolita, wolna od sowieckiej dominacji. Członkowie czy raczej współpracownicy nawiązywali przy tym, nie wiem czy świadomie, do dyrektywy ks. Adama Jerzego Czartoryskiego z czasów Wielkiej Emigracji: „Pierwej być, potem jak być” ${ }^{24}$. Rezultaty ich przemyśleń były następnie kolportowane $\mathrm{w}$ drugim obiegu, prasie emigracyjnej lub rozpowszechniane na falach radiowych Wolnej Europy. Ten typ aktywności nie przysporzył im rozgłosu, jak też szerszego zasięgu społecznego, nie wpłynął też na reorientację głównych nurtów przedsierpniowej opozycji ${ }^{25}$.

Kolejna inicjatywa wyłoniła się w rezultacie sporu programowego, w łonie najbardziej znanej struktury dysydenckiej Komitetu Obrony Robotników, właśnie wokół celowości versus szkodliwości podjęcia przez opozycję hasła niepodległości Polski. Jej zwolennicy skupili się nowej inicjatywie zwanej w środowiskach opozycyjnych pieszczotliwie ROPCiO (Ruch Obrony Praw Człowieka i Obywatela). Centralną postacią stał się tu rychło historyk i publicysta Leszek Robert Moczulski. Rozpoczął on swą oficjalną działalność od opublikowania w marcu 1977 roku, oczywiście poza cenzurą, Apelu do polskiego społeczeństwa, w którym akcentował potrzebę niepodległości. Inicjatorzy planowali, że ROPCiO stanie się jawnie działającym, masowym ruchem obywatelskim. Jego organami prasowymi były

\footnotetext{
${ }^{24}$ Por. M. Kukieł, Książę Adam, Warszawa 1993, s. 127.

${ }^{25}$ Język niepodległości, PPN 1976-1981, oprac. Ł. Bertram, Warszawa 2012, s. 9 i n.
} 
warszawska „Opinia” i gdański „Bratniak”. Stało się jednak inaczej, a to za sprawą operacji służb, która doprowadziła rok później do rozłamu organizacji ${ }^{26}$.

Nieco później wykrystalizowało się kolejne środowisko niepodległościowe skupione wokół pisma „Głos”, którego inicjatorem był Antoni Macierewicz, harcerz i opozycjonista, także o korowskiej proweniencji. Obie te inicjatywy nawiązywały wyraźnie do tradycji i szerzej do dziedzictwa II Rzeczpospolitej.

Jeszcze bardziej zdecydowanie czyniła to Konfederacja Polski Niepodległej, pierwsza opozycyjna partia polityczna w całym bloku wschodnim, która na dodatek nie okazała się jedynie efemerydą. Akt inaugurujący jej działalność został odczytany 1 września 1979 r. przed Grobem Nieznanego Żołnierza ${ }^{27}$. Celem politycznym KPN zawartym w Deklaracji ideowej była sformułowana wprost budowa Trzeciej Rzeczpospolitej. Prowadząca do niej droga („Droga” to także tytuł głównego organu prasowego) została nakreślona w tekście programowym lidera KPN Leszka Moczulskiego zatytułowanym Rewolucja bez rewolucji.

I wreszcie wypada wymienić także utworzony w tym samym czasie i podobnie jak KPN na gruzach ROPCia, Ruch Młodej Polski skupiający w gdańskim mateczniku, zgodnie z nazwą, ludzi młodych o orientacji katolicko-narodowej. Głównym ideologiem tego środowiska i redaktorem pisma „Bratniak” był Aleksander Hall ${ }^{28}$. Do innej epoki, choć to tylko kilka lat różnicy, epoki „Solidarności” należy „Solidarność Walcząca” Kornela Morawieckiego, której nie można pominąć w tym krótkim zestawieniu ${ }^{29}$.

Uformowana w pierwszej poł. XIX w. polska idea niepodległości przetrwała czas zaborów i zatryumfowała na krótko w 1918 r. Polacy przystąpili wówczas z entuzjazmem do budowania nowoczesnego państwa, Polski odrodzonej. Idea niepodległości motywowała jej obrońców w czasie wojny i podtrzymywała czynny opór przed komunistycznym zniewoleniem w latach powojennych, dopóki było to racjonalne. Przechowana w pamięci zbiorowej, przekazana następnym pokoleniom stała się punktem wyjścia dla zarysowanych tu inicjatyw i zaangażowanych w nie osób. I tak na przełomie lat 70. i 80. przygotowany został grunt na przyjęcie papieskiego wezwania Polaków do odpowiedzialnej wolności, obejmującej także prawo narodu do niepodległego bytu. Jego spełnienie nastąpiło równo po 10 latach. Czy ta rozbudzona na nowo idea niepodległości jest dostatecznie mocna by podjęta po raz drugi w XX stuleciu budowa zdrowego i silnego państwo przyniosła sukces? - to kwestia nadal otwarta.

${ }^{26}$ G. Waligóra, Ruch Obrony Praw Człowieka, 1977-1981, Warszawa 2006.

${ }^{27}$ Konfederacja Polski Niepodległej na drodze do wolności, red. M. Wenklar, Kraków 2011, s. 8 i n.

${ }^{28}$ P. Zaremba, Młodopolacy: historia Ruchu Młodej Polski, Gdańsk 2000.

${ }^{29}$ I. Janke, Twierdza: „Solidarność Walcząca”- podziemna armia, Warszawa 2014. 


\section{Abstract \\ The idea of independence in post-war Poland}

The Polish idea of independence was formed in the first half of the $19^{\text {th }}$ century. It allowed the Poles to durably survive the time of the partitions and was short-lived in the autumn of 1918. The Poles then started with enthusiasm to build from scratch a modern state, the Poland Reborn. This idea motivated them to fight against the German and Soviet invasion in 1939 and continued resistance during the Second World War. In time the communist slavery after 1945, it survived in the collective memory of the Poles and was passed on to future generations. It was an important inspiration for some of the opposition circles operating in Poland since 1976. She prepared the ground for receiving the papal message to the Poles during his first pilgrimage to the Fatherland. It contained a call to responsible freedom, including also the right of the nation independent existence. His fulfillment took place equally ten years, in 1989 , thanks to the Solidarity movement.

Keywords: independence, Solidarity movement, Poland 
4. Uniwersytet Papieski

Pfog Jana Pawła II 